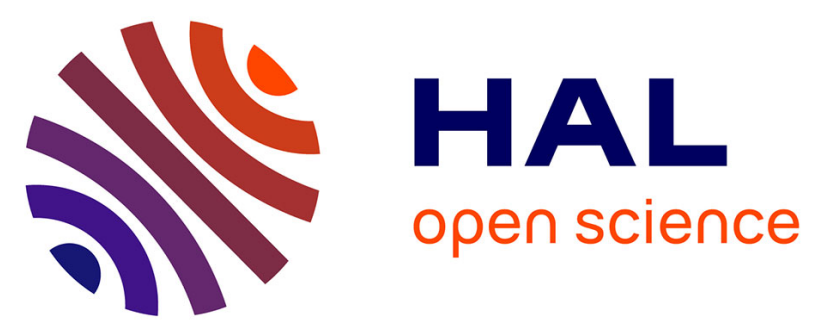

\title{
Tetra-(benzo-24-crown-8)-phthalocyanines as a platform for supramolecular ensembles: Synthesis and interaction with viologen
}

Evgeniya A. Safonova, Jennifer A. Wytko, Jean Weiss, Elena A. Ugolkova, Nikolay N. Efimov, Vadim V. Minin, Yulia G. Gorbunova, Aslan Yu. Tsivadze

\section{To cite this version:}

Evgeniya A. Safonova, Jennifer A. Wytko, Jean Weiss, Elena A. Ugolkova, Nikolay N. Efimov, et al.. Tetra-(benzo-24-crown-8)-phthalocyanines as a platform for supramolecular ensembles: Synthesis and interaction with viologen. Journal of Porphyrins and Phthalocyanines, 2020, 24 (09), pp.1083-1092. 10.1142/S1088424620500297 . hal-02929889

\section{HAL Id: hal-02929889 \\ https://hal.science/hal-02929889}

Submitted on 3 Sep 2020

HAL is a multi-disciplinary open access archive for the deposit and dissemination of scientific research documents, whether they are published or not. The documents may come from teaching and research institutions in France or abroad, or from public or private research centers.
L'archive ouverte pluridisciplinaire HAL, est destinée au dépôt et à la diffusion de documents scientifiques de niveau recherche, publiés ou non, émanant des établissements d'enseignement et de recherche français ou étrangers, des laboratoires publics ou privés. 


\title{
Tetra-(benzo-24-crown-8)-phthalocyanines as a platform for supramolecular ensembles: synthesis and interaction with viologen
}

\author{
Evgeniya A. Safonovaa, Jennifer A. Wytko ${ }^{\mathrm{b}^{*}}$, Jean Weiss ${ }^{\mathrm{b}}$, Elena A. Ugolkovac, Nikolay \\ N. Efimovc, Vadim V. Mininc, Yulia G. Gorbunovaa, ${ }^{a, c^{*}}$, Aslan Yu. Tsivadze ${ }^{a, c}$
}

a A.N. Frumkin Institute of Physical Chemistry and Electrochemistry RAS, 119071, Leninsky pr., 31, building 4, Moscow, Russia

bInstitut de Chimie de Strasbourg, UMR 7177, CNRS, Université de Strasbourg, 4 Rue Blaise Pascal, 67008 Strasbourg, France

${ }^{\mathrm{c}}$ N.S. Kurnakov Institute of General and Inorganic Chemistry RAS, 119991, Leninsky pr., 31, Moscow, Russia

Received date (to be automatically inserted after your manuscript is submitted)

Accepted date (to be automatically inserted after your manuscript is accepted)

\begin{abstract}
The synthesis of a series of novel tetra-(benzo-24-crown-8)-phthalocyanines (Mg(II), Ni(II), $\mathrm{Co}(\mathrm{II})$ ) as well as a modified procedure for the free-base ligand and its $\mathrm{Zn}(\mathrm{II})$ and $\mathrm{Cu}(\mathrm{II})$ complexes are reported. The tendency of these phthalocyanines to undergo supramolecular cofacial dimerization induced by interaction with a viologen ( $N, N$-di(but-3-ynyl)-4,4'-bipyridinium) was investigated by UV-Vis absorption and EPR spectral studies in solution. The nature of the metal cation in phthalocyanine, the concentration, as well as the solvent all influenced the assembly processes.
\end{abstract}

KEYWORDS: phthalocyanine, crown ether, viologen, supramolecular assembly, UV-Vis absorption, EPR spectroscopy

*Correspondence to: jwytko@unistra.fr, yulia@igic.ras.ru 


\section{INTRODUCTION}

The development of molecular machines and switches is on the foremost edge of the today's science [1-5]. Applications of such molecular devices include multiple aspects of modern life [6], medicine [7,8] and electronics [9,10], as well as artificial small-molecule robots [11]. Conceptually, it should be possible to develop materials for information recording and storage with unique density, when one molecule bears one information bit, or for the control of drug delivery with target carriers. Tetrapyrrolic macrocycles are very promising scaffolds for the formation of molecular machines and switches because of their chemical and thermal stability along with their intense absorbance in the UV and visible spectral range and remarkable photochemical and redox properties $[4,12,13]$.

Initially designed for the recognition of alkali and alkaline-earth metal ions, crown ethers have shown strong affinities for ammonium and pyridinium based organic cations and thus have also often been used for molecular machine development [14-17]. Thereby crown-substituted tetrapyrrolic macrocycles [18-20] that integrate the features of both classes of substances may be interesting platforms for the construction of novel molecular machines. For example, tetra-(benzo-24-crown-8)phthalocyanine was used as a versatile building block for the design of a fourfold rotaxane consisting of cofacially stacked homo- or heteronuclear phthalocyanine (Pc) - porphyrin (Por) dimers [21-24]. Switchable spin-spin interactions in such rotaxanes were induced by supramolecular interactions between crown-ethers appended to phthalocyanines and protonated amino groups of a neighboring porphyrin molecule. More complex trinuclear porphyrin-Pc assemblies have been designed by three approaches. The first strategy was the introduction of additional porphyrin molecules as the third deck in the rotaxane structure using specific regognition due to ionic interactions [25]. The second approach involved the assembly of two phthalocyanine molecules onto a porphyrin template containing eight amino-groups to form a heterotrimer $\mathrm{H}_{2} \mathrm{Por}-\mathrm{Cu}(\mathrm{II}) \mathrm{Pc}-$ $\mathrm{Cu}$ (II)Pc [26]. The last approach was the design and synthesis of another type of triple-decker assembly, namely a multiply interlocked catenane with a novel molecular topology, in which four peripheral crown ethers were quadruply interlocked with a cofacial porphyrin dimer bridged with four alkylammonium chains [27].

Today, no example of scaffolds built on phthalocyanines only have been reported in the literature. This work reports the design of a new type of molecular device based on tetra-(benzo-24-crown-8)-phthalocyanine $\mathbf{8 M}$ in which the crown ether ring could bind positively charged viologens to form cofacial dimers (Fig. 1). Since viologens can exist in three distinct redox states, the electrochemical control of the dynamic states could be used for the further design of a devices constructed on the basis of such supramolecular assemblies [28-30]. The ethynyl groups of the viologens offer the future possibility of locking the dimeric structure by a click reaction with bulky azide stoppers. In this work, the synthesis of tetra-(benzo-24-crown-8)substituted phthalocyanine and its metal complexes $\mathbf{8 M}(\mathrm{Mg}(\mathrm{II}), \mathrm{Ni}(\mathrm{II}), \mathrm{Co}(\mathrm{II})), \mathrm{Zn}(\mathrm{II})$ and $\mathrm{Cu}(\mathrm{II}))$ as well as their supramolecular interactions with a viologen ( $N, N$-dibutynyl-4,4'-bipyridinium) are described. The formation of supramolecular cofacial dimers in solution was investigated in detail by UV-Vis and EPR spectroscopy. 


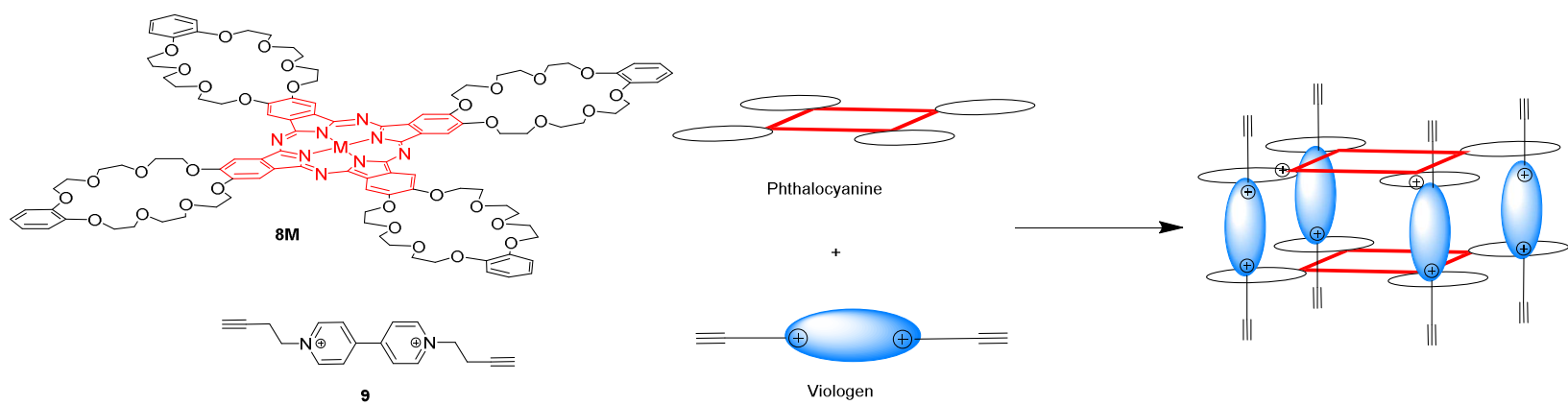

Fig. 1. Viologen-induced formation of cofacial dimers of $\mathbf{8 M}$.

\section{EXPERIMENTAL}

\section{Materials and equipment}

Triethyleneglycol monotosylate (2), 1,2-bis-2'-[2''-(2', '-hydroxyethoxy)-ethoxy]-ethoxy \}-benzene (3) and 1,1'-di(but-3ynyl)-4,4'-bipyridine-1,1'-diium bis(hexafluorophosphate (9) were synthesized by previously reported procedures [31-33].

Triethyleneglycol (1), p-toluenesulphonylchloride ( $\mathrm{TsCl}$ ), $\mathrm{NaOH}, \mathrm{K}_{2} \mathrm{CO}_{3}$, catechol, $N$-bromosuccinimide (NBS), $\mathrm{I}_{2}$, imidazole, triphenylphosphine $\left(\mathrm{PPh}_{3}\right), \mathrm{Cs}_{2} \mathrm{CO}_{3}, \mathrm{Zn}(\mathrm{CN})_{2}, \mathrm{Pd}_{2}(\mathrm{dba})_{3}$, dppf, $\mathrm{Cu}(\mathrm{OAc})_{2}, \mathrm{Zn}(\mathrm{OAc})_{2} \bullet 2 \mathrm{H}_{2} \mathrm{O} \mathrm{Mg}(\mathrm{OAc})_{2} \bullet \mathrm{H}_{2} \mathrm{O}, \mathrm{Mg}$, $\mathrm{Co}(\mathrm{OAc})_{2} \bullet 4 \mathrm{H}_{2} \mathrm{O}, \mathrm{Ni}(\mathrm{acac})_{2}, \mathrm{CF}_{3} \mathrm{COOH}, 1,8$-diazabicyclo[5.4.0]-undec-7-ene (DBU) and the solvents (tetrahydrofuran (THF), N,N-dimethylformamide (DMF), N,N-dimethylacetamide (DMA), pentanol, dichlorobenzene, dichloromethane, chloroform, ethanol and methanol) were available from commercial suppliers (Acros, Merck, Aldrich, and Sigma). Pentanol was distilled over magnesium under argon. DBU was distilled over $\mathrm{CaH}_{2}$ under reduced pressure, and stored under argon. Chloroform (stabilized with $0.6-1 \%$ ethanol) was dried over $\mathrm{CaCl}_{2}$ and distilled over $\mathrm{NaHCO}_{3}$. Other reagents were used without additional purification. Neutral alumina (Merck) and silica gel (Macherey Nagel, Kieselgel 60) were used for column chromatography. Bio-Beads SX-1 (BIO-RAD) was used for size-exclusion chromatography.

NMR spectra were recorded on Bruker Avance 600 and Bruker Avance 300 spectrometers. NMR spectra were referenced to the residual solvent signals [27]. UV-Vis spectra were measured with a Thermo Evolution 210 spectrometer in quartz cells with a $1 \mathrm{~cm}$ and $0.1 \mathrm{~cm}$ optical path equipped with Peltier thermostating accessory.

Matrix-assisted laser desorption ionization time-of-flight mass spectra (MALDI-TOF MS) were measured on a Bruker Daltonics Ultraflex spectrometer with 2,5-dihydroxybenzoic acid as the matrix. High-resolution mass spectrometry (HRMS) experiments were performed on a Bruker Daltonics microTOF spectrometer (Bruker Daltonik GmgH, Bremen, Germany) by the Service de Spectrométrie de Masse de la Fédération de Chimie "Le Bel" (FR 2010).

X-Band EPR spectra were measured at $9.8 \mathrm{GHz}$ microwave frequency on Bruker Elexsys E-680X radiospectrometer at $90 \mathrm{~K}$. Resulting EPR spectra of $\mathbf{8 C o}$ and $\mathbf{8 C u}$ were described using rhombic spin Hamiltonian with Zeeman, hyperfine and super hyperfine interactions (equation 1).

$$
\begin{aligned}
& H=g_{z} \beta H_{z} S_{z}+g_{x} \beta H_{x} S_{x}+g_{y} \beta H_{y} S_{y}+A I_{z} S_{z}+B I_{x} S_{x}+C I_{y} S_{y}+ \\
& \beta \sum_{\alpha}\left(g_{z} a_{z}^{\alpha} S_{z} I_{z}^{\alpha}+g_{x} a_{x}^{\alpha} S_{x} I_{x}^{\alpha}+g_{y} a_{y}^{\alpha} S_{y} I_{y}^{\alpha}\right)
\end{aligned}
$$

Here $g_{z}, g_{x}, g_{\mathrm{y}}-z, x, y$ - components of $g$-tensor, $A, B, C-z, x, y$ - components of HFS tensor, $S_{z}, S_{x}, S_{y}$ - projections of spin operator onto coordination axes, $S=1 / 2, I_{z}, I_{x}, I_{y}$ - projections of nuclear spin operator onto coordination axes, $I_{C u}=3 / 2$, $I_{C o}=7 / 2 . I^{i}=1-$ nuclear spin of nitrogen, $a_{z}, a_{x}, a_{y}$-components of super hyperfine tensor in Gauss. 
Resulting EPR spectrum of $\mathbf{8 C u + v i o l o g e n}$ is the sum of the dimer spectrum with $\mathrm{S}=1$ and the monomer spectrum with $\mathrm{S}=1 / 2$ and it was described using spin Hamiltonian with fine interactions for $\mathrm{S}=1$ (equation 2).

$$
H=\beta\left(g_{x} S_{x} H_{x}+g_{y} S_{y} H_{y}+g_{z} H_{z} S_{z}\right)+D\left(S_{z}^{2}-S(S+1) / 3\right)
$$

Where $D$ is the component of fine interaction tensor.

The parameters of EPR spectra were found using best approximation method, which minimizes the error function (equation $3)$.

$$
F=\sum_{i}\left(Y_{i}^{T}-Y_{i}^{E}\right)^{2} / N
$$

Here $Y_{i}^{E}$ - the array of the observed intensities of EPR signals at different values of magnetic field $H, Y_{i}^{T}-$ theoretical values of intensities at the same values of magnetic field $H, N$-number of points.

Theoretical spectra were plotted according to the previously reported procedure [34]. Line shapes were described using Gaussian and Lorentzian functions [35]. The line widths were parameterized using relaxation theory [36] (equation 4).

$$
\sigma_{k}=\alpha_{k}+\beta_{k} m_{I}+\gamma_{k} m_{I}^{2}
$$

Here $m_{I^{-}}$projection of nuclear spin on the magnetic field direction, $k=x, y, z, \alpha_{k}, \beta_{k}, \gamma_{k}$ - broadening parameters in corresponding orientations. Minimization of error function implied variation of $g$-factors, HFS and super hyperfine constants, line widths and shapes.

\section{Synthesis}

Preparation of 4,5-bis-2'-[2',-(2','-hydroxyethoxy)-ethoxy]-ethoxy\}-1,2-dibromobenzene (4). A solution of NBS (2.29 $\mathrm{g}, 16.4 \mathrm{mmol})$ in $20 \mathrm{~mL}$ of DMF was added to a solution of $\mathbf{3}(2.19 \mathrm{~g}, 7.5 \mathrm{mmol})$ in $20 \mathrm{~mL}$ of DMF. The reaction mixture was stirred for 3 days open to air at room temperature. A saturated aqueous solution of $\mathrm{Na}_{2} \mathrm{SO}_{3}$ was added. The reaction mixture was filtered and the solvent from filtrate was evaporated. The resulting compound was purified by chromatography on silica by gradient elution with mixture of hexane- $\mathrm{CH}_{2} \mathrm{Cl}_{2}-\mathrm{EtOH}(1: 1: 0-0: 95: 5)$, yielding $2.67 \mathrm{~g}$ of 4 as a yellowish oil $(86 \%) .{ }^{1} \mathrm{H}$ $\operatorname{NMR}\left(600 \mathrm{MHz}, \mathrm{CDCl}_{3}\right) \delta 7.15\left(\mathrm{~s}, 1 \mathrm{H}, \mathrm{H}_{\mathrm{Ar}}\right), 4.15-4.18\left(\mathrm{~m}, 2 \mathrm{H}, \mathrm{a}_{1}\right), 3.84-3.93\left(\mathrm{~m}, 2 \mathrm{H}, \mathrm{a}_{2}\right), 3.73-3.77$ (m, 4H, $\left.\mathrm{a}_{3}, \mathrm{a}_{4}\right), 3.68-3.72$ $\left(\mathrm{m}, 2 \mathrm{H}, \mathrm{a}_{5}\right), 3.62-3.64\left(\mathrm{~m}, 2 \mathrm{H}, \mathrm{a}_{6}\right)$.

Preparation of 4,5-bis-2'-[2"'-(2'”'-iodoethoxy)-ethoxy]-ethoxy\}-1,2-dibromobenzene (5). $\mathrm{PPh}_{3}(2.33 \mathrm{~g}, 9.1 \mathrm{mmol})$ and $\mathrm{I}_{2}$ $\left(2.22 \mathrm{~g}, 8.7 \mathrm{mmol}\right.$ ) were dissolved in $85 \mathrm{~mL}$ of $\mathrm{CH}_{2} \mathrm{Cl}_{2}$ (freshly distilled over $\left.\mathrm{CaCl}_{2}\right)$ and then imidazole $(1.16 \mathrm{~g}, 17.0 \mathrm{mmol}$ ) was added. The mixture was stirred for $10 \mathrm{~min}$ and then $1(0.968 \mathrm{~g}, 18.2 \mathrm{mmol})$ was added. The reaction mixture was stirred for $2 \mathrm{~h}$ at room temperature, then a solution of $\mathrm{Na}_{2} \mathrm{SO}_{3}(0.97 \mathrm{~g}, 7.7 \mathrm{mmol})$ in $15 \mathrm{~mL}$ of water was added. The organic layer was separated and the solvent was evaporated. The resulting compound was purified by column chromatography on silica by gradient elution with a mixture of hexane- $\mathrm{CH}_{2} \mathrm{Cl}_{2}-\mathrm{EtOH}(1: 1: 0-0: 95: 5)$ to afford $0.84 \mathrm{~g}$ of 5 as a yellow oil $(61 \%) .{ }^{1} \mathrm{H} \mathrm{NMR}$ $\left(600 \mathrm{MHz}, \mathrm{CDCl}_{3}\right) \delta$, ppm: $7.15\left(\mathrm{~s}, 1 \mathrm{H}, \mathrm{H}_{\mathrm{Ar}}\right), 4.14\left(\mathrm{t}, \mathrm{J}=4.9 \mathrm{~Hz}, 2 \mathrm{H}, \mathrm{a}_{1}\right), 3.86\left(\mathrm{t}, \mathrm{J}=4.9 \mathrm{~Hz}, 2 \mathrm{H}, \mathrm{a}_{2}\right), 3.76(\mathrm{t}, \mathrm{J}=6.8 \mathrm{~Hz}, 2 \mathrm{H}$, $\left.\mathrm{a}_{3}\right), 3.72\left(\mathrm{~m}, 2 \mathrm{H}, \mathrm{a}_{4}\right), 3.68\left(\mathrm{~m}, 2 \mathrm{H}, \mathrm{a}_{5}\right), 3.26\left(\mathrm{t}, \mathrm{J}=6.8 \mathrm{~Hz}, 2 \mathrm{H}, \mathrm{a}_{6}\right) .{ }^{13} \mathrm{C}-\mathrm{NMR}\left(151 \mathrm{MHz}, \mathrm{CDCl}_{3}\right) \delta, \mathrm{ppm}: 149.0,119.4,115.6$, 72.2, 71.1, 70.5, 69.9, 69.5, 3.1. HRMS ESI: $\mathrm{m} / \mathrm{z}$ calculated for $\mathrm{C}_{18} \mathrm{H}_{26} \mathrm{Br}_{2} \mathrm{I}_{2} \mathrm{O}_{6}\left[\mathrm{M}+\mathrm{nNH}_{4}\right]^{+}-769.8504, \mathrm{~m} / \mathrm{z}$ found $[\mathrm{M}+\mathrm{nNH}]^{+}$ - 769.8511; m/z calculated for $[\mathrm{M}+\mathrm{nNa}]^{+}-774.8058, \mathrm{~m} / \mathrm{z}$ found $[\mathrm{M}+\mathrm{nNa}]^{+}-774.8079 ; \mathrm{m} / \mathrm{z}$ found $\mathrm{for} \mathrm{C}_{18} \mathrm{H}_{26} \mathrm{Br}_{2} \mathrm{I}_{2} \mathrm{O}_{6}$ $[\mathrm{M}+\mathrm{nK}]^{+}-790.7798, \mathrm{~m} / \mathrm{z}$ found $[\mathrm{M}+\mathrm{nK}]^{+}-790.7799$.

Preparation of 4',5'-dibromodibenzo-24-crown-8-ether (6). A solution of 5 (1.20 g, $1.6 \mathrm{mmol})$ and catechol (0.17 g, 1.6 $\mathrm{mmol})$ in $10 \mathrm{~mL}$ of DMF was added by syringe pump over $10 \mathrm{~h}$ to a suspension of $\mathrm{Cs}_{2} \mathrm{CO}_{3}(2.60 \mathrm{~g}, 8.0 \mathrm{mmol}) \mathrm{in} 50 \mathrm{~mL}$ of $\mathrm{DMF}$ at $80^{\circ} \mathrm{C}$ in argon. Then reaction mixture was stirred for $2 \mathrm{~h}$ and cooled to room temperature. The resulting mixture was 
filtered and the solvent from filtrate was evaporated. The resulting compound was purified by chromatography on silica in a mixture of $\mathrm{CH}_{2} \mathrm{Cl}_{2}$ - $\mathrm{EtOH}(95: 5)$ to yield $0.52 \mathrm{~g}$ of 6 as a colorless solid (54\%). M.p. $=101-104{ }^{\circ} \mathrm{C} .{ }^{1} \mathrm{H} \mathrm{NMR}(600 \mathrm{MHz}$, $\left.\mathrm{CDCl}_{3}\right) \delta$, ppm: $7.06\left(\mathrm{~s}, 1 \mathrm{H}, \alpha-\mathrm{H}_{\mathrm{Ar}}\right), 6.85-6.91\left(\mathrm{~m}, 2 \mathrm{H}, \beta, \gamma-\mathrm{H}_{\mathrm{Ar}}\right), 4.13-4.16\left(\mathrm{~m}, 2 \mathrm{H}, \mathrm{CH}_{2}\right), 4.09-4.11\left(\mathrm{~m}, 2 \mathrm{H}, \mathrm{CH}_{2}\right), 3.87$ - $3.92\left(\mathrm{~m}, 4 \mathrm{H}, \mathrm{CH}_{2}\right), 3.81\left(\mathrm{dd}, \mathrm{J}=6.5,2.0 \mathrm{~Hz}, 4 \mathrm{H}, \mathrm{CH}_{2}\right) .{ }^{13} \mathrm{C}-\mathrm{NMR}\left(151 \mathrm{MHz}, \mathrm{CDCl}_{3}\right) \delta$, ppm: 149.1, 149.0, 121.6, 118.6, $115.4,114.3,71.5,71.4,70.1,70.0,69.8,69.5$.

Preparation of 8',9'-benzo-24-crown-8-phthalonitrile (7). To a degassed mixture of 6 (270 mg, $450 \mu \mathrm{mol}), \mathrm{Zn}(\mathrm{CN})_{2}(84$ $\mathrm{mg}, 710 \mu \mathrm{mol}), \mathrm{Pd}_{2}(\mathrm{dba})_{3}(20 \mathrm{mg}, 30 \mu \mathrm{mol})$ and dppf $(21 \mathrm{mg}, 37 \mu \mathrm{mol}), 4 \mathrm{~mL}$ of DMA were added. The mixture was refluxed for $2 \mathrm{~h}$, cooled to room temperature, diluted with $\mathrm{CH}_{2} \mathrm{Cl}_{2}$ and filtered over a pad of alumina. The solvent was evaporated and the resulting product was purified by column chromatography on alumina $\left(\mathrm{CH}_{2} \mathrm{Cl}_{2}\right.$-EtOH (95:5)) to yield $0.204 \mathrm{mg}$ of 7 as a brownish solid (91\%). M.p. $=104-107{ }^{\circ} \mathrm{C} .{ }^{1} \mathrm{H}$ NMR $\left(600 \mathrm{MHz}, \mathrm{CDCl}_{3}\right) \delta$, ppm: $7.11\left(\mathrm{~s}, 1 \mathrm{H}, \alpha-\mathrm{H}_{\mathrm{Ar}}\right), 6.83-6.92(\mathrm{~m}, 2 \mathrm{H}, \beta, \gamma-$ $\left.\mathrm{H}_{\mathrm{Ar}}\right), 4.17-4.23\left(\mathrm{~m}, 2 \mathrm{H}, \mathrm{CH}_{2}\right), 4.10-4.16\left(\mathrm{~m}, 2 \mathrm{H}, \mathrm{CH}_{2}\right), 3.87-3.97\left(\mathrm{~m}, 4 \mathrm{H}, \mathrm{CH}_{2}\right), 3.81\left(\mathrm{~s}, 4 \mathrm{H}, \mathrm{CH}_{2}\right) .{ }^{13} \mathrm{C}-\mathrm{NMR}(151 \mathrm{MHz}$, $\left.\mathrm{CDCl}_{3}\right) \delta$, ppm: 152.5, 149.0, 121.7, 116.5, 115.8, 114.2, 109.1, 71.7, 71.4, 70.7, 70.2, 70.1, 69.4.

Preparation of $\mathbf{M g}\left[(\mathrm{B24C8})_{4} \mathbf{P c}\right]$ (8Mg). Method 1. A mixture of phthalonitrile 7 (200 mg, $\left.402 \mu \mathrm{mol}\right), \mathrm{Mg}(\mathrm{OAc})_{2}(28 \mathrm{mg}$, $201 \mu \mathrm{mol})$ and $\mathrm{DBU}(60 \mu \mathrm{l}, 400 \mu \mathrm{mol})$ in $5 \mathrm{~mL}$ of pentanol was refluxed overnight under argon. Then reaction mixture was cooled to room temperature and poured into hexane. The resulting precipitate was filtered, washed with hexane and dissolved in $\mathrm{CHCl}_{3}$. Solvent was evaporated under vacuum. The product was purified by size-exclusion chromatography on column packed with Bio-Beads $\mathrm{SX}-1$ in $\mathrm{CHCl}_{3}+2.5 \mathrm{vol} \% \mathrm{MeOH}$ yielding $80 \mathrm{mg}$ of green solid (39\%).

Method 2. A mixture of phthalonitrile 7 (200 mg, $402 \mu \mathrm{mol})$, and metallic $\mathrm{Mg}(19 \mathrm{mg}, 804 \mu \mathrm{mol})$ in $10 \mathrm{~mL}$ of pentanol was refluxed overnight under argon. The reaction mixture was cooled to room temperature and poured into hexane. The resulting precipitate was filtered, washed with hexane and dissolved in $\mathrm{CHCl}_{3}$. Solvent was evaporated under vacuum. The product was purified by size-exclusion chromatography with Bio-Beads SX-1 in $\mathrm{CHCl}_{3}+2.5$ vol \% $\mathrm{MeOH}$ to yield $130 \mathrm{mg}$ of $\mathbf{8 M g}$ as a green solid (64\%). HRMS ESI, m/z: calculated for $\mathrm{C}_{104} \mathrm{H}_{120} \mathrm{MgN}_{8} \mathrm{O}_{32}-2017,7884$, found - 2017.7847. ${ }^{1} \mathrm{H}$ NMR $\left(600 \mathrm{MHz}, \mathrm{CDCl}_{3}\right) \delta$, ppm: $8.93\left(\mathrm{~s}, 1 \mathrm{H}, \alpha-\mathrm{H}_{\mathrm{Ar}}\right), 6.78-6.85\left(\mathrm{~m}, 2 \mathrm{H}, \beta, \gamma-\mathrm{H}_{\mathrm{Ar}}\right), 4.67-4.73$ (bs, 2H, $\left.\mathrm{CH}_{2}\right), 3.72-4.23\left(\mathrm{~m}, 10 \mathrm{H}, \mathrm{CH}_{2}\right)$. UV-Vis $\left(\mathrm{CHCl}_{3}\right), \lambda$, $\mathrm{nm}(\log (\varepsilon)): 678$ (5.30), 613 (4.53), 360 (4.92), 283 (5.08).

Preparation of $\mathrm{H}_{2}\left[(\mathbf{B 2 4 C 8})_{4} \mathbf{P c}\right](\mathbf{8 H 2}) . \mathrm{CF}_{3} \mathrm{COOH}(0.5 \mathrm{~mL}, 650 \mu \mathrm{mol})$ was added to a solution of $\mathbf{8 M g}(77 \mathrm{mg}, 38 \mu \mathrm{mol})$ in $12 \mathrm{~mL}$ of $\mathrm{CHCl}_{3}$ and the reaction mixture was refluxed for $10 \mathrm{~min}$. The mixture was cooled to room temperature and neutralized with $\mathrm{Et}_{3} \mathrm{~N}(1 \mathrm{~mL}, 650 \mu \mathrm{mol})$. Solvents were removed under vacuum. The resulting product was dissolved in $\mathrm{CHCl}_{3}$ and washed with water. The organic layer was dried with $\mathrm{Na}_{2} \mathrm{SO}_{4}$ and the solvent was evaporated. Column chromatography over alumina in a $\mathrm{CH}_{2} \mathrm{Cl}_{2} / \mathrm{MeOH}$ mixture (95:5) afforded a green compound, which was further purified by repetitive sizeexclusion chromatography (Bio-Beads SX-1 in $\mathrm{CHCl}_{3}+2.5$ vol \% MeOH). Yield: $63 \mathrm{mg}(80 \%)$. MALDI-TOF MS, m/z: calculated for $\mathrm{C}_{104} \mathrm{H}_{122} \mathrm{~N}_{8} \mathrm{O}_{32}-1995.82$, found - 1995.8. ${ }^{1} \mathrm{H}$ NMR $\left(600 \mathrm{MHz}, \mathrm{CDCl}_{3}\right) \delta$, ppm: $8.58\left(\mathrm{~s}, 1 \mathrm{H}, \alpha-\mathrm{H}_{\mathrm{Ar}}\right), 6.77-6.86$ (m, 2H, $\beta, \gamma-\mathrm{H}_{\mathrm{Ar}}$ ), 4.72-4.77 (bs, 2H, $\left.\mathrm{CH}_{2}\right), 4.23-4.33\left(\mathrm{~m}, 2 \mathrm{H}, \mathrm{CH}_{2}\right), 4.15-4.21\left(\mathrm{~m}, 2 \mathrm{H}, \mathrm{CH}_{2}\right), 4.05-4.09\left(\mathrm{~m}, 2 \mathrm{H}, \mathrm{CH}_{2}\right), 3.96-$ 4.02 (m, 4H, $\mathrm{CH}_{2}$ ). UV-Vis $\left(\mathrm{CHCl}_{3}\right), \lambda$, nm (log(ع)): 701 (5.10), 663 (5.02), 602 (4.39), 420 (4.56), 348 (4.90), 294 (4.75).

Preparation of Zn[(B24C8) $\left.{ }_{4} P c\right](8 Z n)$. A mixture of phthalonitrile 7 (100 mg, $\left.200 \mu \mathrm{mol}\right)$, and Zn(OAc) $)_{2} 2 \mathrm{H} 2 \mathrm{O}(19 \mathrm{mg}$, $100 \mu \mathrm{mol})$ in $7 \mathrm{~mL}$ of pentanol was heated to reflux and then DBU $(30 \mu \mathrm{l}, 200 \mu \mathrm{mol})$ was added. The reaction mixture was refluxed overnight under argon, then cooled to room temperature and poured into hexane. The resulting precipitate was filtered, washed with hexane and dissolved in $\mathrm{CHCl}_{3}$. Solvent was evaporated under vacuum. The product was purified by size-exclusion chromatography (Bio-Beads SX-1 in $\mathrm{CHCl}_{3}+2.5 \mathrm{vol} \% \mathrm{MeOH}$ ) to yield $90 \mathrm{mg}$ of $\mathbf{8 Z n}$ as a green solid $(87 \%)$. HRMS ESI, calculated for $\mathrm{C}_{104} \mathrm{H}_{120} \mathrm{ZnN}_{8} \mathrm{O}_{32}-2058.7317$, found - 2058.7306. ${ }^{1} \mathrm{H}$ NMR (300 MHz, $\left.\mathrm{CDCl}_{3}\right) \delta, \mathrm{ppm}$ : 8.87 (s, 
$\left.1 \mathrm{H}, \alpha-\mathrm{H}_{\mathrm{Ar}}\right), 6.79-6.88\left(\mathrm{~m}, 2 \mathrm{H}, \beta, \gamma-\mathrm{H}_{\mathrm{Ar}}\right), 4.74$ (bs, 2H, $\left.\mathrm{CH}_{2}\right), 4.16-4.24\left(\mathrm{~m}, 4 \mathrm{H}, \mathrm{CH}_{2}\right), 4.01-4.06\left(\mathrm{~m}, 2 \mathrm{H}, \mathrm{CH}_{2}\right), 3.92-4.00$ (m, $\left.4 \mathrm{H}, \mathrm{CH}_{2}\right)$. UV-Vis $\left(\mathrm{CHCl}_{3}\right), \lambda, \mathrm{nm}(\log (\varepsilon)): 680$ (5.14), 614 (4.71), 358 (4.24).

Preparation of $\mathrm{Ni}\left[(\mathrm{B} 24 \mathrm{C8})_{4} \mathrm{Pc}\right](\mathbf{8 N i})$. A mixture of $\mathbf{8 H 2}(50 \mathrm{mg}, 25 \mu \mathrm{mol})$ and $\mathrm{Ni}(\mathrm{acac})_{2}(13 \mathrm{mg}, 50 \mu \mathrm{mol})$ in $10 \mathrm{~mL}$ of dichlorobenzene was refluxed for 15 min under argon. The reaction mixture was cooled to r.t. and poured into hexane. The resulting precipitate was filtered, washed with hexane and dissolved in $\mathrm{CHCl}_{3}$. Solvent was evaporated under vacuum. The product was purified by size-exclusion chromatography (Bio-Beads $\mathrm{SX}-1$ in $\mathrm{CHCl}_{3}+2.5 \mathrm{vol} \% \mathrm{MeOH}$ ) to yield $42 \mathrm{mg}$ of 8Ni blueish-green solid (82\%). HRMS ESI m/z: calculated for $\mathrm{C}_{104} \mathrm{H}_{120} \mathrm{NiN}_{8} \mathrm{O}_{32}-2051.7389$, found - 2051.7342. ${ }^{1} \mathrm{H}$ NMR $\left(600 \mathrm{MHz}, \mathrm{CDCl}_{3}\right) \delta$, ppm: $8.18\left(\mathrm{~s}, 1 \mathrm{H}, \alpha-\mathrm{H}_{\mathrm{Ar}}\right), 6.75-6.84\left(\mathrm{~m}, 2 \mathrm{H}, \beta, \gamma-\mathrm{H}_{\mathrm{Ar}}\right), 4.65-4.72\left(\mathrm{bs}, 2 \mathrm{H}, \mathrm{CH}_{2}\right), 4.23-4.32\left(\mathrm{bs}, 2 \mathrm{H}, \mathrm{CH}_{2}\right)$, 4.14-4.21 (m, 2H, $\left.\mathrm{CH}_{2}\right)$, 4.05-4.10 (m, 2H, $\left.\mathrm{CH}_{2}\right), 3.96-4.02\left(\mathrm{~m}, 4 \mathrm{H}, \mathrm{CH}_{2}\right)$. UV-Vis $\left(\mathrm{CHCl}_{3}\right), \lambda, \operatorname{nm}(\log (\varepsilon)): 668(5.22), 604$ (4.49), 407 (4.46), 310 (4.83), 286 (4.90).

Preparation of Co[(B24C8) ${ }_{4} \mathbf{P c}$ ] (8Co). A mixture of $\mathbf{8 H 2}(30 \mathrm{mg}, 15 \mu \mathrm{mol}), \mathrm{Co}(\mathrm{OAc})_{2}(5 \mathrm{mg}, 30 \mu \mathrm{mol})$, and DBU (5 $\mu \mathrm{l}$, $15 \mu \mathrm{mol}$ ) in $10 \mathrm{~mL}$ of DMF was refluxed for $30 \mathrm{~min}$ under argon. The reaction mixture was cooled to r.t. and poured into water. The resulting precipitate was filtered, washed with water and dissolved in $\mathrm{CHCl}_{3}$. Solvent was evaporated under vacuum. The product was purified by size-exclusion chromatography (Bio-Beads SX-1 in $\mathrm{CHCl}_{3}+2.5$ vol \% $\mathrm{MeOH}$ ) to yield $24 \mathrm{mg}$ of 8Co as a blueish green solid (78\%). HRMS ESI m/z: calculated for $\mathrm{C}_{104} \mathrm{H}_{120} \mathrm{CoN}_{8} \mathrm{O}_{32}-2052.7368$, found 2052.7366. found - 2052.7. ${ }^{1} \mathrm{H}$ NMR (600 MHz, $\left.\mathrm{CDCl}_{3}\right) \delta$, ppm: 10.66 (s, $1 \mathrm{H}, \alpha-\mathrm{H}_{\mathrm{Ar}}$ ), 6.78-6.87 (bs, 2H, $\left.\beta, \gamma-\mathrm{H}_{\mathrm{Ar}}\right), 4.98-5.07$ (bs, 2H, $\mathrm{CH}_{2}$ ), 4.54-4.62 (bs, 2H, $\left.\mathrm{CH}_{2}\right), 4.23-4.31$ (m, 4H, $\left.\mathrm{CH}_{2}\right), 4.05-4.17$ (m, 4H, $\left.\mathrm{CH}_{2}\right)$. UV-Vis $\left(\mathrm{CHCl}_{3}\right), \lambda, \mathrm{nm}(\log (\varepsilon)$ ): 670 (5.06), 606 (4.49), 402 (4.33), 298 (4.87).

Preparation of $\mathbf{C u}\left[(\mathbf{B 2 4 C 8})_{4} \boldsymbol{P c}\right](\mathbf{8 C u})$. Phthalocyanine $\mathbf{8 H 2}(48 \mathrm{mg}, 24 \mu \mathrm{mol})$, was dissolved in $8 \mathrm{~mL}$ of DMF and heated to reflux under argon, then $\mathrm{Cu}(\mathrm{OAc})_{2} * 2 \mathrm{H}_{2} \mathrm{O}(22 \mathrm{mg}, 98 \mu \mathrm{mol})$ was added in two portions and the mixture was refluxed for $105 \mathrm{~min}$. The reaction mixture was cooled to r.t. and poured into water. The resulting precipitate was filtered, washed with water and dissolved in $\mathrm{CHCl}_{3}$. Solvent was evaporated under vacuum. Column chromatography on alumina in a $\mathrm{CH}_{2} \mathrm{Cl}_{2} / \mathrm{MeOH}$ (95:5) mixture afforded a green compound, which was further purified by repetitive size-exclusion chromatography (Bio-Beads SX-1 in $\mathrm{CHCl}_{3}+2.5$ vol \% MeOH). Yield: $36 \mathrm{mg}(72 \%)$. HRMS ESI, m/z: calculated for $\mathrm{C}_{104} \mathrm{H}_{120} \mathrm{CoN}_{8} \mathrm{O}_{32}-2057.7332$, found - 2057.7302. UV-Vis $\left(\mathrm{CHCl}_{3}\right), \lambda, \mathrm{nm}\left(\log (\varepsilon)_{1}\right): 678(5.26), 611(4.51), 412$ (4.46), 341 (4.84).

\section{RESULTS AND DISCUSSION}

\section{Synthesis and characterization}

The benzo-24-crown-8-phthalonitrile - precursor 7 [37] of the target phthalocyanines - was synthesized by a modified sixstep method as shown in Scheme 1. Instead of the previously described tosylation of 4, iodination was carried out to give compound 5 in moderate yield. In addition, use of a Pd-catalyzed cyanation in the last step instead of a classical RosenmundBraun reaction increased the yield of 6 from $55 \%$ up to $91 \%$ [37]. 


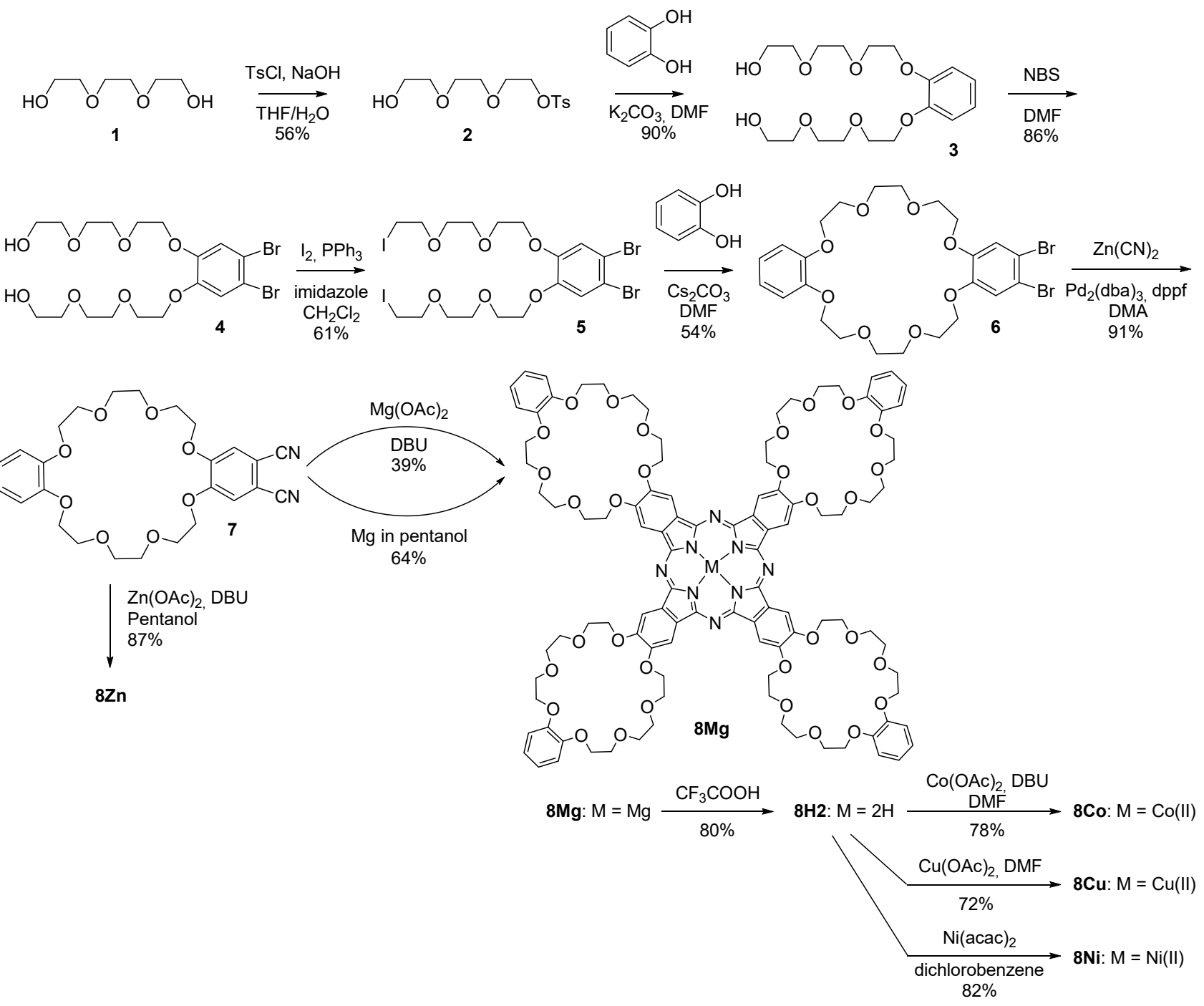

Scheme 1. Synthesis of di-(benzo-24-crown-8)-phthalonitrile 7 and tetra-(benzo-24-crown-8)-phthalocyanines $8 \mathbf{M}$ $(\mathrm{M}=\mathrm{Mg}(\mathrm{II}), \mathrm{Zn}(\mathrm{II}), \mathrm{Co}(\mathrm{II}), \mathrm{Cu}(\mathrm{II}), \mathrm{Ni}(\mathrm{II}), \mathrm{H} 2)$.

The target metal complexes were synthesized using a template approach $(\mathbf{8 M g}$ and $\mathbf{8 Z n})$ or by metalation of free-base phthalocyanine $8 \mathrm{H} 2$ with the corresponding metal salts $(\mathbf{8 C o}, 8 \mathrm{Cu}, \mathbf{8 N i}$ ) (Scheme 1). Thus, complex $\mathbf{8 M g}$ was obtained by template condensation of phthalonitrile 7 with $\mathrm{Mg}(\mathrm{OAc})_{2}$ in the presence of DBU with a quite low, 39\% yield. Interestingly, the replacement of $\mathrm{Mg}(\mathrm{OAc})_{2}$ and $\mathrm{DBU}$ with metallic $\mathrm{Mg}$ in the template reaction increased the yield up to 64\%. Using the template method for the synthesis of the previously described $\mathbf{8 Z n}$ afforded this product with a 2.6 times higher yield (87\%) than by using two-step procedure (synthesis of free base ligand $\mathbf{8 H 2}$ and its metalation, 33\%) [22].

Phthalocyanine $8 \mathrm{H} 2$ was obtained by demetalation of $8 \mathrm{Mg}$ with trifluoroacetic acid. This two-step synthesis of $8 \mathrm{H} 2$ in $51 \%$ yield appeared to be more efficient than the previously described synthesis with a reported yield of 34\% starting from phthalonitrile [21]. Complexes $\mathbf{8 C o}, 8 \mathbf{N i}$ and $\mathbf{8 C u}$ were synthesized from phthalocyanine $\mathbf{8 H 2}$ by metalation with the corresponding metal salts and were isolated with reasonably high yields (78\%, $82 \%$ and $72 \%$, respectively). The metalated compounds were purified by column chromatography on alumina followed by repetitive size-exclusion chromatography on 
columns packed with Bio-Beads SX-1. All products were characterized by NMR (Fig. 2, Figs. S1-S10), UV-Vis (Fig. 3, Figs. S11-S14), HR ESI MS (Fig. S15-20), and EPR (Fig. 4-6) spectroscopies.

The molecular structure of the $\mathbf{8 N i}$ complex was confirmed by its ${ }^{1} \mathrm{H}$ NMR spectrum in $\mathrm{CDCl}_{3}$ which shows two resonance signals of aromatic protons at 8.27 and 6.75-7.84 ppm and five signals of crown ether protons in the aliphatic region of 3.80$4.80 \mathrm{ppm}$ (Fig. 2). The ${ }^{1} \mathrm{H}$ NMR spectra of $\mathbf{8 H 2}$ and $\mathbf{8 Z n}$ (Fig. S8-S10) are similar, with the same set of the signals. In contrast, the spectrum of complex $\mathbf{8 M g}$ consists of broad signals that suggest aggregation processes in solution. Surprisingly, despite the paramagnetic nature of the $\mathrm{Co}$ (II) nucleus of $\mathbf{8 C o}$, it was possible to obtain an informative ${ }^{1} \mathrm{H}$ NMR spectrum, which displayed broad signal at low field centered at $10.64 \mathrm{ppm}$ for the phthalocyanine aromatic protons and four sets of signals for the crown ether protons (Fig. 2).

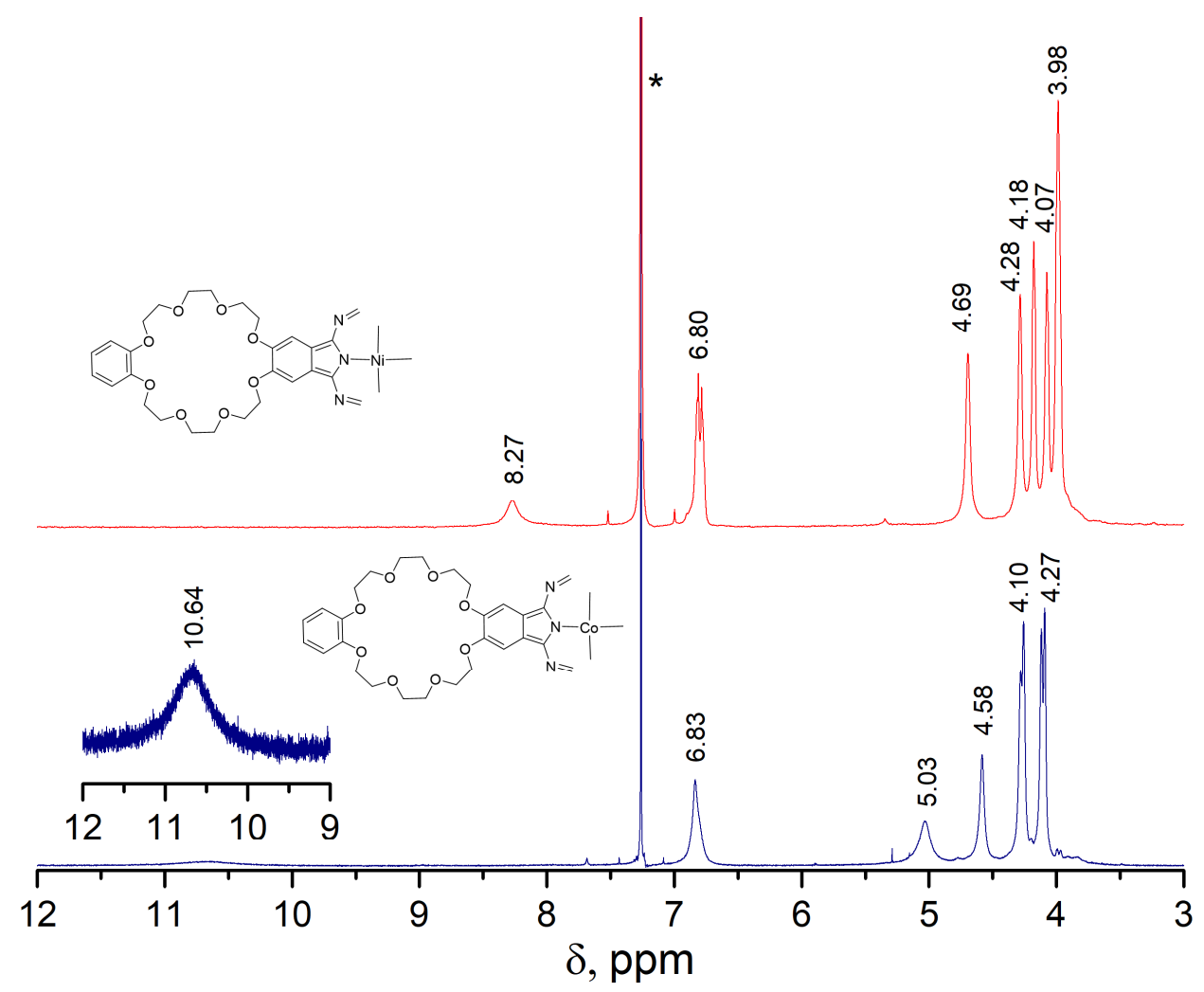

Fig. 2. ${ }^{1} \mathrm{H}-\mathrm{NMR}$ spectra of $\mathbf{8 N i}$ (top) and $\mathbf{8 C o}$ (bottom) in $\mathrm{CDCl}_{3}$.

\section{UV-Vis properties}

The UV-Vis spectrum of $\mathbf{8 H 2}$ in $\mathrm{CHCl}_{3}$ at $\mathrm{c} \approx 10^{-5} \mathrm{M}$ displays two intense Q-bands at 662 and 698 nm followed by wellresolved vibrational satellite at $601 \mathrm{~nm}$ and a B-band at $348 \mathrm{~nm}$ that are typical for monomeric phthalocyanines (Fig. 3, Figs. S11-S14, Table 1) [38]. The broad band at $420 \mathrm{~nm}$ corresponds to a charge transfer band from lone pairs of oxygen atoms to the phthalocyanine aromatic system [39]. Due to the higher symmetry of the metal complexes, only one Q-band, in the 668$681 \mathrm{~nm}$ region, is observed in the spectra of $\mathbf{8 M}$ solutions, as shown for $\mathbf{8 N i}$ in Figure 3. 

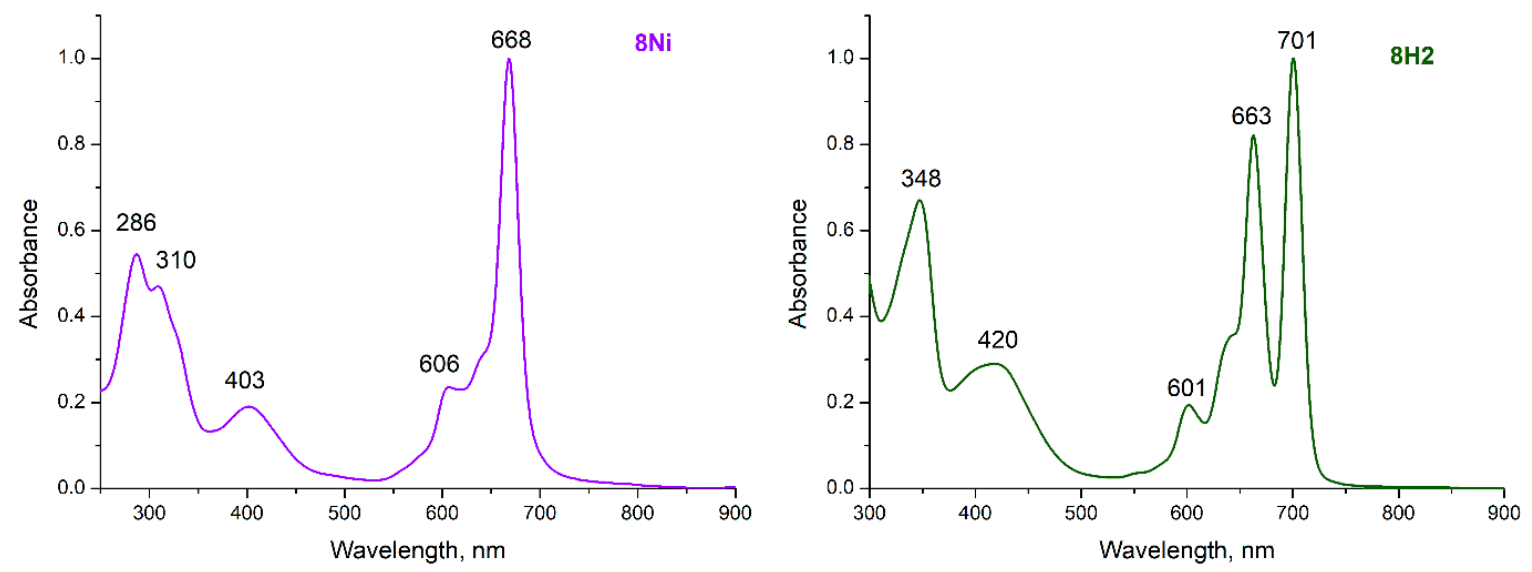

Fig. 3. Normalized UV-Vis spectra of $\mathbf{8} \mathbf{H} 2$ (right) and $\mathbf{8 N i}$ (left) in $\mathrm{CHCl}_{3}$.

Table 1. The wavelengths of the Q- and B-bands of $\mathbf{8 M}$ in the UV-Vis spectra in $\mathrm{CHCl}_{3}$.

\begin{tabular}{|c|c|c|c|c|c|c|}
\hline & $\mathbf{8 H 2}$ & $\mathbf{8 M g}$ & $\mathbf{8 Z n}$ & $\mathbf{8 N i}$ & $\mathbf{8 C o}$ & $\mathbf{8 C u}$ \\
\hline $\begin{array}{c}\text { Q-band, } \mathrm{nm} \\
(\log (\varepsilon))\end{array}$ & $\begin{array}{c}663(5.02), \\
701(5.10)\end{array}$ & $678(5.30)$ & $680(5.14)$ & $668(5.22)$ & $670(5.06)$ & $678(5.26)$ \\
\hline $\begin{array}{c}\text { B-band, } \mathrm{nm} \\
(\log (\varepsilon))\end{array}$ & $348(4.90)$ & $\begin{array}{c}283(5.08), \\
360(4.92)\end{array}$ & $358(4.24)$ & $286(4.90)$, & $298(4.87)$ & $341(4.84)$ \\
\end{tabular}

\section{EPR investigations}

Due to the paramagnetic nature of the $\mathrm{Co}(\mathrm{II})$ and $\mathrm{Cu}(\mathrm{II})$ complexes, $\mathbf{8 C o}$ and $\mathbf{8 C u}$ were also characterized by EPR spectroscopy. The spectrum of complex $\mathbf{8 C u}$ was recorded in frozen $\mathrm{CH}_{2} \mathrm{Cl}_{2}$ at $90 \mathrm{~K}$. Pyridine was added to the solution to prevent aggregation. The spectrum displays hyperfine interaction of spin $\mathrm{S}=1 / 2$ with the nuclear spin of copper $\mathrm{I}=3 / 2$ and super hyperfine interaction with four equivalent nitrogen nuclei $\mathrm{I}_{\mathrm{N}}=1$ (Fig 4). The parameters $\left(\mathrm{g}_{\mathrm{z}}=2.152, \mathrm{~g}_{\mathrm{x}}=2.033, \mathrm{~g}_{\mathrm{y}}=\right.$ 2.037, $A=1.932 \cdot 10^{-2} \mathrm{~cm}^{-1}, B=2.067 \cdot 10^{-3} \mathrm{~cm}^{-1}, C=2.011 \cdot 10^{-3} \mathrm{~cm}^{-1}, a_{z}(\mathrm{Pc})=14.82 \mathrm{Gs}, a_{x}(\mathrm{Pc})=16.33 \mathrm{Gs}, a_{y}(\mathrm{Pc})=16.96$ Gs) are typical for species of this type (Fig. 3) [40,41].

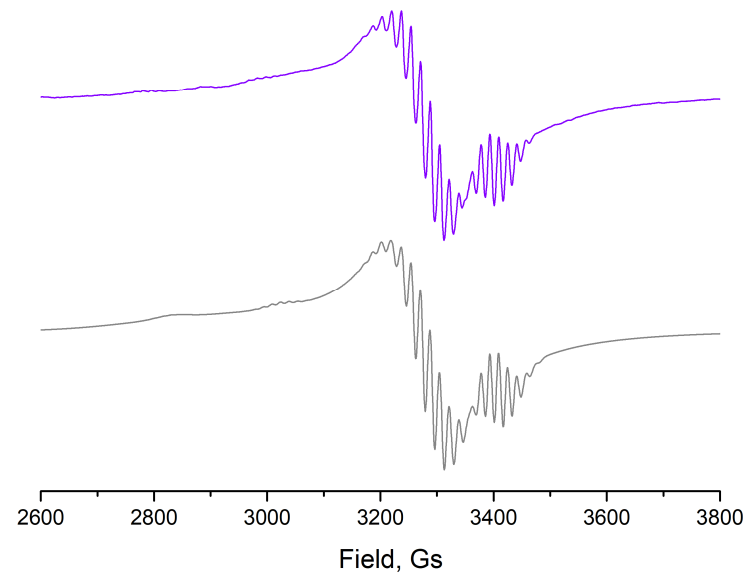

Fig. 4. EPR spectra of $\mathbf{8 C u}$ in $\mathrm{CH}_{2} \mathrm{Cl}_{2}$-pyridine (9:1) at $90 \mathrm{~K}$ - experimental (violet) and theoretical (grey). 
The EPR spectrum of $\mathbf{8 C o}$ in $\mathrm{CHCl}_{3}$ (Fig. 5) reveals hyperfine structure from interaction of spin $\mathrm{S}=1 / 2$ with the nuclear spin of cobalt $\mathrm{I}=7 / 2$ with parameters: $\mathrm{g}_{\mathrm{z}}=1.990, \mathrm{~g}_{\mathrm{x}}=2.352, \mathrm{~g}_{\mathrm{y}}=2.410, A=1.156 \cdot 10^{-2} \mathrm{~cm}^{-1}, B=5.325 \cdot 10^{-3} \mathrm{~cm}^{-1}, C=8.168 \cdot 10^{-}$ ${ }^{3} \mathrm{~cm}^{-1}$. It is very important to mention that $4.8 \%$ of $\mathbf{8 C o}$ is coordinated to $\mathrm{O}_{2}$. The parameters for $\mathbf{8 C o}-\mathbf{O}_{2}$ complex are: $\mathrm{g}_{z}=$ 1.985, $\mathrm{g}_{\mathrm{x}}=1.995, \mathrm{~g}_{\mathrm{y}}=2.058, A=1.007 \cdot 10^{-3} \mathrm{~cm}^{-1}, B=1.694 \cdot 10^{-3} \mathrm{~cm}^{-1}, C=2.344 \cdot 10^{-3} \mathrm{~cm}^{-1}$. In addition, the observation of a prohibited transition signal in the spectrum of $\mathbf{8 C o}$ in $\mathrm{CHCl}_{3}$ at $1600 \mathrm{Gs}$ provided evidence for the partial aggregation of the complex.

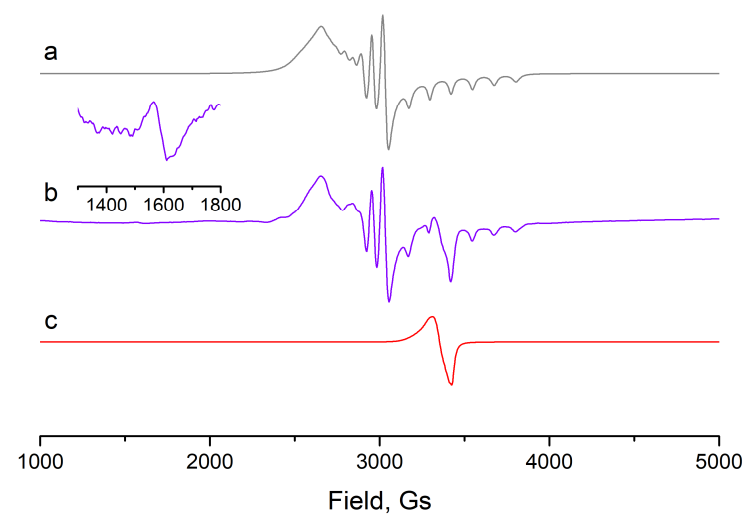

Fig. 5. EPR spectrum of $\mathbf{8 C o}$ in $\mathrm{CHCl}_{3}$ at $90 \mathrm{~K}$ (b) and theoretical spectra of $\mathbf{8 C o}$ (a) and $\mathbf{8 C o -} \mathbf{-}$ (c).

Addition of pyridine to the 8Co solution led to significant changes in the EPR spectrum (Fig. 6). The disappearance of the signal at $1600 \mathrm{Gs}$ signified the suppression of aggregation process. On the other hand, super hyperfine interactions with the coordinated pyridine nitrogen nucleus $\mathrm{I}_{\mathrm{N}}=1$ appeared. The amount of $\mathbf{8 C o -} \mathbf{O}_{2}$ complex in the mixture increased more than 10 times - up to $53.9 \%$. This increase is similar to results described earlier for cobalt(II) phthalocyanine [34]. New parameters for monomeric 8Co are $\mathrm{g}_{\mathrm{z}}=2.003, \mathrm{~g}_{\mathrm{x}}=2.229, \mathrm{~g}_{\mathrm{y}}=2.216, A=9.690 \bullet 10^{-3} \mathrm{~cm}^{-1}, B=2.390 \bullet 10^{-3} \mathrm{~cm}^{-1}, C=2.400 \bullet 10^{-3} \mathrm{~cm}^{-1}, a_{z}(\mathrm{Pyr})$ $=17.40 \mathrm{Gs}, a_{x}(\mathrm{Pyr})=6.99 \mathrm{Gs}, a_{y}(\mathrm{Pyr})=7.75 \mathrm{Gs}$ and for $\mathbf{8 C o}-\mathbf{O}_{2}$ complex, the parameters are $\mathrm{g}_{\mathrm{z}}=1.999, \mathrm{~g}_{\mathrm{x}}=2.009, \mathrm{~g}_{\mathrm{y}}=$ $2.061, A=1.053 \cdot 10^{-3} \mathrm{~cm}^{-1}, B=1.069 \cdot 10^{-3} \mathrm{~cm}^{-1}, C=1.974 \cdot 10^{-3} \mathrm{~cm}^{-1}$.

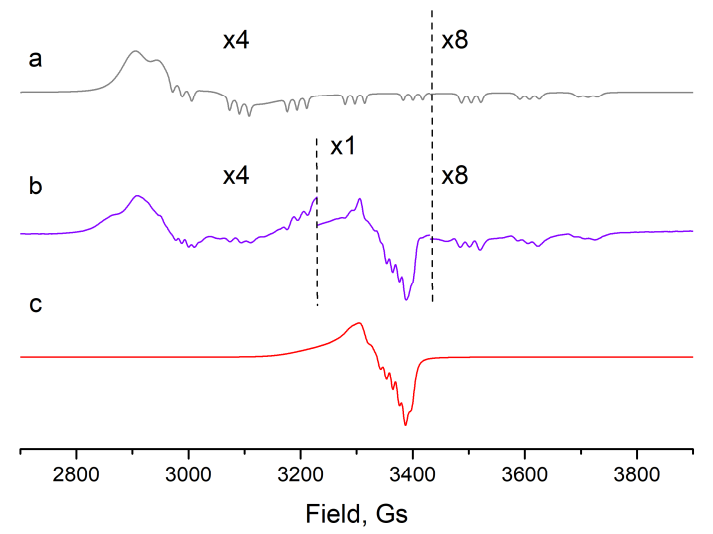

Fig. 6. EPR spectrum of $\mathbf{8 C o}$ in frozen $\mathrm{CHCl}_{3}$-pyridine mixture (4:1) at $90 \mathrm{~K}$ (b) and theoretical spectra of $\mathbf{P y}-\mathbf{8 C o}$ (a) and $\mathrm{Py}-8 \mathrm{Co}-\mathrm{O}_{2}(\mathrm{c})$. 


\section{The host-guest interactions of MPc with viologen}

Next, the interaction of tetra-(benzo-24-crown-8)-phthalocyanine and its host-guest complexes with viologen $9(N, N$ dibutynyl-4,4'-bipyridinium) [33] was investigated by UV-Vis and EPR spectroscopy. Unfortunately, NMR spectroscopy was not informative, probably due to the presence of several different aggregated forms in solution (Fig. S21).

Complex $\mathbf{8 N i}$ was chosen as the main object of the supramolecular assembly investigation because of the absence of axial ligands on the central nickel cation that should prevent formation of cofacial dimer. The addition of viologen 9 in acetone or $\mathrm{MeCN}$ to a $\mathrm{CH}_{2} \mathrm{Cl}_{2}$ solution of $\mathbf{8 N i}$ led to significant hypochromic and hypsochromic shifts (56 $\mathrm{nm}$ ) of the Q band in UV-Vis spectrum, which are typical for the formation of cofacial Pc dimers [40,42] (Fig. 7a). Surprisingly, these changes were not observed in the case of $\mathrm{CHCl}_{3}$ solution (Fig. S22), thus, it seems that solvent plays a very important role in the supramolecular aggregation [40]. On the other hand, the solvent in which the viologen was dissolved also plays an important role. Thus, it was demonstrated that acetone was more efficient than acetonitrile for dimerization of Pc (Fig. 7a) probably due to lower polarity of the acetone compared to acetonitrile. Furthermore, the amount of polar solvent should not be higher than $20 \%$ in the final solution. Further increases of the amount of polar solvent led to aggregation of starting compound and the dimerization was not observed. Additionally, increasing the concentration of $\mathbf{8 N i}$ from $10^{-5}$ up to $10^{-4} \mathbf{M}$ led to more efficient supramolecular assembling (Fig. S23). The partial aggregation of $\mathbf{8 N i}$ due to $\pi$ - $\pi$ stacking at higher concentration could lead to preorganization of the molecules which would facilitate the formation of cofacial dimers. Dilution studies showed that deviation from Beer-Lambert-Bouguer law in the spectra of $\mathbf{8 N i}$ in $\mathrm{CH}_{2} \mathrm{Cl}_{2}$ solutions starts at concentrations above $10^{-6}$ (Fig. S24). Unfortunately, the ratio of dimers and monomers in the solution could not be determined from the UV-visible spectra because of overlapping of their low energy absorption bands.
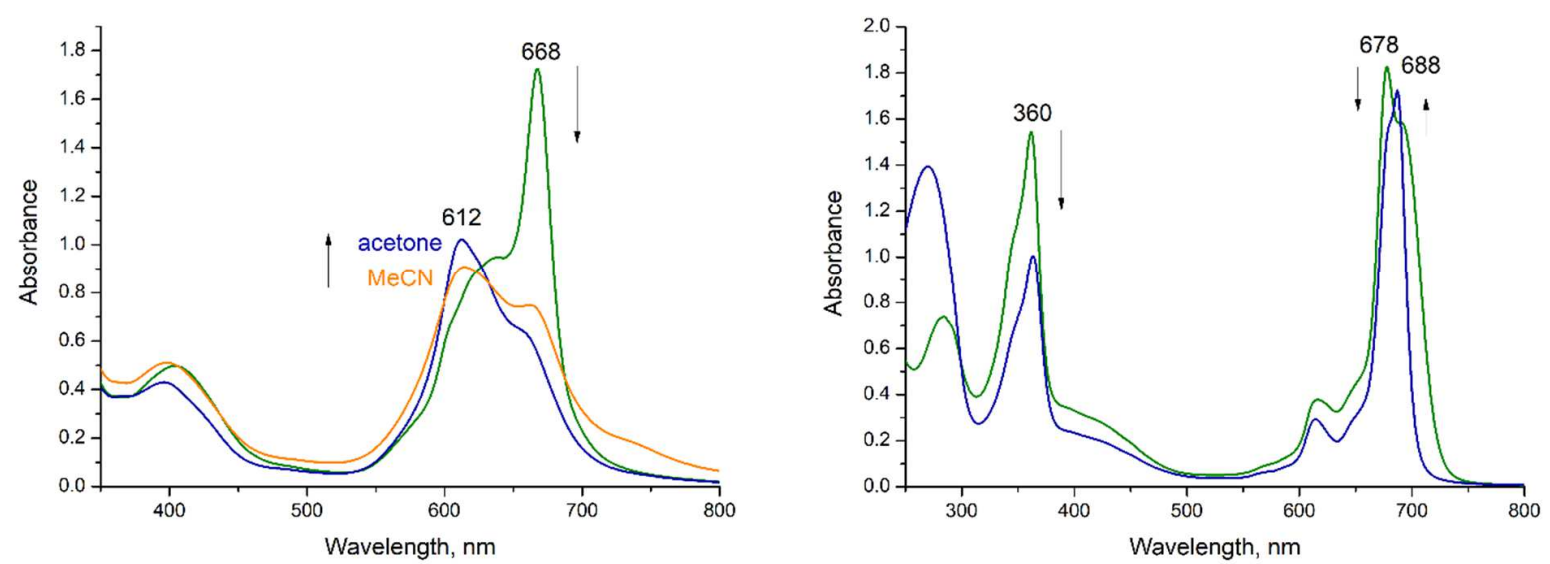

Fig. 7. UV-Vis spectra of $\mathbf{8 N i}$ (left) and $\mathbf{8 M g}$ (right) in $\mathrm{CH}_{2} \mathrm{Cl}_{2}\left(\mathrm{c}=10^{-4} \mathrm{M}\right)$ upon addition of viologen $(2 \mathrm{eq}$.) in $\mathrm{MeCN}$ (orange spectrum) or acetone (blue spectra).

Furthermore, the nature of the central metal cation appeared to play a crucial role in supramolecular processes. Addition of viologen 9 to solutions of $\mathbf{8 H 2}$ and $\mathbf{8 C u}$ led to the changes in UV-Vis spectra similar to those observed for $\mathbf{8 N i}$ (Figs. S2526). However, complexes $\mathbf{8 Z n}, \mathbf{8 M g}$ and $\mathbf{8 C o}$ demonstrated completely different behavior upon addition of viologen. Only minor bathochromic shifts of the Q-band were observed, suggesting the formation of other types of supramolecular aggregates (Fig. 7b, Figs. S27-28). This phenomenon can be explained by the difference in the coordination environment of the central metal atoms. It is well known that cations such as $\mathrm{Zn}(\mathrm{II}), \mathrm{Mg}(\mathrm{II})$ and $\mathrm{Co}$ (II) coordinated in a phthalocyanine are able to bind 
additional axial ligands $[43,44]$. EPR studies in this work demonstrated that 8 Co can easily form complexes with axially coordinated $\mathrm{O}_{2}$. Earlier it was shown that $\mathrm{H}_{2} \mathrm{O}$ molecules as an axial ligands on $\mathrm{Mg}(\mathrm{II})$ and $\mathrm{Zn}$ (II) phthalocyanines can sterically hinder the formation of cofacial dimers [43].

Due to the paramagnetic nature of $\mathrm{Cu}(\mathrm{II})$ atom, EPR spectroscopy can be used as an additional method to investigate the supramolecular behavior of $\mathbf{8 C u}$ in the presence of viologen $\mathbf{9}$. The cobalt complex $\mathbf{8 C o}$ was not investigated because the UV-Vis study demonstrated that cofacial dimers were not observed upon addition of viologen. The addition of a solution of viologen in acetone to a solution of $\mathbf{8 C u}$ in $\mathrm{CH}_{2} \mathrm{Cl}_{2}$ led to the appearance in EPR spectrum at $90 \mathrm{~K}$ of two additional signals with $\mathrm{S}=1$, which are characteristic of a cofacial dimer [45-48] (Fig. 8, Fig. S29). The parameters are: $|D|=0.0608 \mathrm{~cm}^{-1}, g_{z}$ $=2.160, g_{x}=2.013, g_{y}=2.013$. The experimental spectrum matches the theoretical one (Fig. S29). Based on the supposition that zero field splitting is caused by dipole-dipole interaction, the $\mathrm{Cu}-\mathrm{Cu}$ distance can be calculated as $\mathrm{R} \sim 3.6 \AA$. The distance between two charged nitrogen atoms in viologen is 7.07A, which is notacibly larger, however crown-ethers are conformationally labile, which thus allow the molecules to form dimers. Nevertheless, the signal at $\mathrm{H} 3300 \mathrm{Gs}$ indicates the presence of the monomeric form of $\mathbf{8 C u}$ with $\mathrm{S}=1 / 2$. The ratio of monomer/dimer in the solution is $79 / 21$, but it is important to mention that part of the dimer could be in the $S=0$ state and, thus, would not be observed in the spectrum.

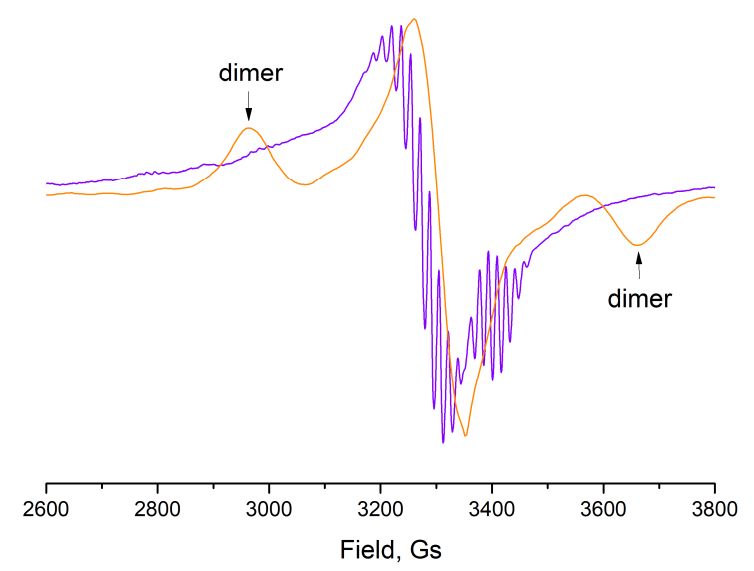

Fig. 8. EPR spectrum of $\mathbf{8 C u}$ in $\mathrm{CH}_{2} \mathrm{Cl}_{2}$ (violet) and after addition of viologen 9 (2 eq.) in acetone (orange) at $90 \mathrm{~K}$.

\section{CONCLUSION}

A series of tetra-(benzo-24-crown-8)-substituted phthalocyanines and its $\mathrm{Mg}(\mathrm{II}), \mathrm{Zn}(\mathrm{II}), \mathrm{Cu}(\mathrm{II}), \mathrm{Ni}(\mathrm{II})$ and $\mathrm{Co}(\mathrm{II})$ complexes were synthesized and characterized by UV-VIS absorption, HR ESI MS, NMR and EPR spectroscopies. Compounds $8 \mathrm{H} 2,8 \mathrm{Ni}$ and $\mathbf{8 C u}$ form cofacial dimers by supramolecular interactions with viologen molecules in $\mathrm{CH}_{2} \mathrm{Cl}_{2}$. On the contrary, no evidence of cofacial dimers was observed for complexes $\mathbf{8 M g}, \mathbf{8 Z n}$ and $\mathbf{8 C o}$, where axial ligands probably prevent this process due to steric hindrance. The important role of solvent and concentration in supramolecular aggregation was also demonstrated. Preorganization of the Pc molecules by $\pi$ - $\pi$ stacking seems to be necessary for further supramolecular dimerization. EPR spectroscopy was shown to be efficient in determining the monomer/dimer ratio in assemblies of $\mathbf{8 C u}$ and viologen 9. These results could be useful for further application of tetra-(benzo-24-crown-8)-substituted phthalocyanines as a platform in the design of a supramolecular devices and switches. 


\section{Acknowledgements}

The authors are grateful to Russian Science Foundation (grant \#18-73-00249). The measurements were performed using equipment of CKP FMI IPCE RAS and IGIC RAS. JAW and JW gratefully acknowledge the CNRS and the University of Strasbourg for financial support.

\section{REFERENCES}

1. $\quad$ Sauvage J-P. Angew. Chemie - Int. Ed. 2017; 56: 11080-11093.

2. Cheng C and Stoddart JF. ChemPhysChem 2016: 1780-1793.

3. Baroncini M, Casimiro L, de Vet C, Groppi J, Silvi S and Credi A. ChemistryOpen 2018; 7: 169-179.

4. Martynov AG, Safonova EA, Tsivadze AY and Gorbunova YG. Coord. Chem. Rev. 2019; 387: 325-347.

5. Kay ER and Leigh DA. Angew. Chemie - Int. Ed. 2015; 54: 10080-10088.

6. Moulin E, Faour L, Carmona-Vargas CC and Giuseppone N. Adv. Mater. 2019; 32: 1906036.

7. Lerch MM, Hansen MJ, van Dam GM, Szymanski W and Feringa BL. Angew. Chemie - Int. Ed. 2016; 55: 1097810999.

8. Ambrogio MW, Thomas CR, Zhao YL, Zink JI and Stoddart JF. Acc. Chem. Res. 2011; 44: $903-913$.

9. Balzani V, Semeraro M, Venturi M and Credi A. In Molecular Switches. Weinheim, Germany: Wiley-VCH Verlag GmbH \& Co. KGaA, 2011; 595-627.

10. Green JE, Wook Choi J, Boukai A, Bunimovich Y, Johnston-Halperin E, DeIonno E, Luo Y, Sheriff BA, Xu K, Shik Shin Y, Tseng H-R, Stoddart JF and Heath JR. Nature 2007; 445: 414-417.

11. Kassem S, Lee ATL, Leigh DA, Markevicius A and Solà J. Nat. Chem. 2016; 8: 138-143.

12. Meshkov IN, Bulach V, Gorbunova YG, Kyritsakas N, Grigoriev MS, Tsivadze AY and Hosseini MW. Inorg. Chem. 2016; 55: 10774-10782.

13. Faiz JA, Heitz V and Sauvage J-P. Chem. Soc. Rev. 2009; 38: 422-442.

14. Coutrot F. ChemistryOpen 2015; 4: 556-576.

15. Balzani V, Gómez-López M and Stoddart JF. Acc. Chem. Res. 1998; 31: 405-414.

16. Braunschweig AB, Ronconi CM, Han J-Y, Aricó F, Cantrill SJ, Stoddart JF, Khan SI, White AJP and Williams DJ. European J. Org. Chem. 2006; 2006: 1857-1866.

17. Huang F, Gantzel P, Nagvekar DS, Rheingold AL and Gibson HW. Tetrahedron Lett. 2006; 47: $7841-7844$.

18. Koray AR, Ahsen V and Bekâroğlu Ö. J. Chem. Soc., Chem. Commun. 1986: 932-933.

19. Yang C, He R, Sun Q, Chen Y and Jiang J. J. Porphyr. Phthalocyanines 2019; 23: 507-517.

20. Martynov AG, Gorbunova YG and Tsivadze AY. Russ. J. Inorg. Chem. 2014; 59: 1635-1664.

21. Yamada Y, Okamoto M, Furukawa K, Kato T and Tanaka K. Angew. Chemie Int. Ed. 2012; 51: 709-713.

22. Yamada Y, Mihara N and Tanaka K. Dalton Trans. 2013; 42: 15873-15876.

23. Mihara N, Yamada Y and Tanaka K. Bull. Chem. Soc. Jpn. 2017; 90: 427-435.

24. Mihara N, Yamada Y, Takaya H, Kitagawa Y, Aoyama S, Igawa K, Tomooka K and Tanaka K. Chem. - A Eur. J. 2017; 23: 7508-7514.

25. Yamada Y, Mihara N, Shibano S, Sugimoto K and Tanaka K. J. Am. Chem. Soc. 2013; 135: 11505-11508.

26. Yamada Y, Kato T and Tanaka K. Chem. - A Eur. J. 2016; 22: 12371-12380.

27. Yamada Y, Itoh R, Ogino S, Kato T and Tanaka K. Angew. Chemie - Int. Ed. 2017; 56: 14124-14129. 
28. Le Poul N and Colasson B. ChemElectroChem 2015; 2: 475-496.

29. Berville M, Karmazin L, Wytko JA and Weiss J. Chem. Commun. 2015; 51: 15772-15775.

30. Berville M, Choua S, Gourlaouen C, Boudon C, Ruhlmann L, Bailly C, Cobo S, Saint-Aman E, Wytko J and Weiss J. ChemPhysChem 2017; 18: 796-803.

31. Wu L, He Y-M and Fan Q-H. Adv. Synth. Catal. 2011; 353: 2915-2919.

32. Zhou Y, Chen Y, Zhu P-P, Si W, Hou J-L and Liu Y. Chem. Commun. 2017; 53: 3681-3684.

33. Coskun A, Saha S, Aprahamian I and Stoddart JF. Org. Lett. 2008; 10: 3187-3190.

34. Rakitin YV, Larin GM and Minin V V. Interpretation of ESR Spectra of Coordination Compounds (in Russian). Moscow: Nauka; 1993.

35. Lebedev YS and Muromtsev VI. ESR and Relaxation of Stabilized Radicals (in Russian). Moscow: Khimiya; 1972.

36. Wilson R and Kivelson D. J. Chem. Phys. 1966; 44: 154-168.

37. Martínez-Díaz MV, Fender NS, Rodríguez-Morgade MS, Gómez-López M, Diederich F, Echegoyen L, Stoddart JF and Torres T. J. Mater. Chem. 2002; 12: 2095-2099.

38. Fukuda T and Kobayashi N. In Handbook of Porphyrin Science., 2010; 1-644.

39. Belosludov R V., Nevonen D, Rhoda HM, Sabin JR and Nemykin VN. J. Phys. Chem. A 2019; 123: $132-152$.

40. Kobayashi N and Lever ABP. J. Am. Chem. Soc. 1987; 109: 7433-7441.

41. Finazzo C, Calle C, Stoll S, Van Doorslaer S and Schweiger A. Phys. Chem. Chem. Phys. 2006; 8: $1942-1953$.

42. Martynov AG, Nefedova I V., Efimov NN, Ugolkova EA, Minin V V, Gorbunova YG and Tsivadze AY. Macroheterocycles 2018; 11: 390-395.

43. Safonova EA, Martynov AG, Nefedov SE, Kirakosyan GA, Gorbunova YG and Tsivadze AY. Inorg. Chem. 2016; 55: $2450-2459$.

44. Kramer WW and McCrory CCL. Chem. Sci. 2016; 7: 2506-2515.

45. Smith TD and Pilbrow JR. Coord. Chem. Rev. 1974; 13: 173-278.

46. Kottis P and Lefebvre R. J. Chem. Phys. 1963; 39: 393-403.

47. Thomson C. Q. Rev. Chem. Soc. 1968; 22: 45-74.

48. Eaton SS, More KM, Sawant BM, Boymel PM and Eaton GR. J. Magn. Reson. 1983; 52: 435-449. 